\title{
Lord Walton of Detchant
}

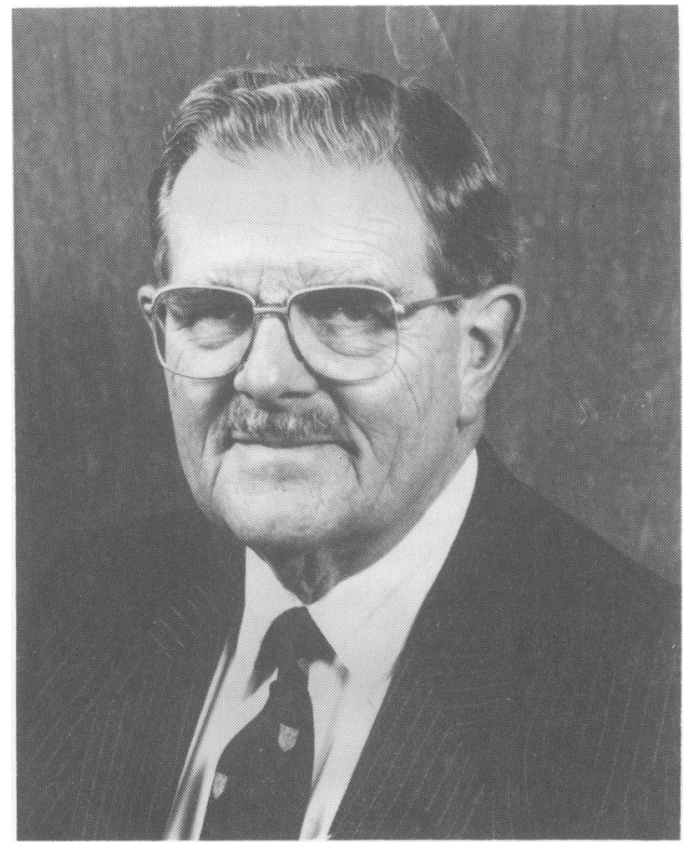

Few doctors became legends, and even fewer in their own lifetime. But - first, some facts. John Walton was born in Rowlands Gill, Co. Durham, England on 16 September 1922 and was educated at the Alderman Wraith Grammar School, Spennymoor, Co. Durham. He entered Durham University Medical School in Newcastle-upon-Tyne in 1941 and qualified in December 1945 with first class honours, having obtained distinctions in all subjects in his professional examinations. During his student career he was awarded the Turnbull, Outterson Wood, Gibson and Phillipson Prizes and was elected President of the Medical SubCouncil of the Students' Representative Council and Treasurer of the British Medical Students' Association. After qualification he was house physician to Professor F.J. Nattrass and later house physician to Professor J.C. Spence in the Royal Victoria Infirmary, Newcastle-upon-Tyne.

He joined the Army in March 1947 and served first as Embarkation Medical Officer to Scottish ports and later in Southampton before becoming second-in-command of Hospital Ship Oxfordshire and later of Hospital Ship El Nil. In 1952 he joined the Territorial Army and from November 1963 to November 1966 commanded the 1(N) General
Hospital (TA) with the rank of Colonel, later becoming Honorary Colonel (1976-1981).

After demobilization in 1949 he was appointed medical registrar to Dr Henry Miller at the Royal Victoria Infirmary, obtaining the M.R.C.P. in January 1950 and the M.D. in June 1952. In 1951 he was appointed research assistant in the Department of Medicine to undertake work on muscle disease with Professor F.J. Nattrass and held this appointment until June 1956. From October 1953 he worked for one year as Nuffield Foundation Medical Fellow in the Department of Neurology at the Massachusetts General Hospital, Boston, Mass, USA and in Harvard University. He collaborated with Dr Raymond Adams to produce their monograph on 'Polymyositis'. From October 1954, for one year, he was King's College Travelling Fellow in Medicine at the Neurological Research Unit of the National Hospital, Queen Square, London under the direction of Dr E.A Carmichael. During this period he was for 2 years Chairman of the Registrar's Group Committee of Members of the Royal College of Physicians.

In 1956 he was appointed First Assistant in Neurology to the Royal Victoria Infirmary and in June 1958 Consultant Neurologist to the New- 
castle General Hospital and Royal Victoria Infirmary. In 1968 he was appointed Professor of Neurology and from 1971 served for 10 years as Dean of Medicine in the University of Newcastleupon-Tyne.

In October 1983 he left Newcastle-upon-Tyne to succeed Sir Richard Doll as Warden of Green College, Oxford, an appointment from which he retired at the end of September 1989, when he became an Honorary Fellow of the College. In Oxford he continued in limited clinical practice in neurology as honorary consultant neurologist to the Oxford health authorities, attending a weekly session in muscle disease.

He was awarded the D.Sc. by the University of Newcastle-upon-Tyne in 1972 and was made an Honorary Freeman of the City of Newcastle in 1980. His honorary degrees include Dr de l'Univ (Hon) (Aix-Marseille) (1975), Hon. D.Sc. Leeds (1979), Leicester (1980) and Hull (1988), Hon.M.D. Sheffield (1987), Hon.D.C.L. Newcastle-uponTyne (1988), Honorary Fellowship of the American College of Physicians (1980), of the Royal College of Physicians of Edinburgh (1981) and of the Royal College of Physicians of Canada (1984). Other awards include becoming a Foreign Member of the Norwegian Academy of Science and Letters (1987), Honorary Member of the American Neurological Association and Corresponding Member of the American Academy of Neurology, Honorary Foreign Member of the Société Francaise de Neurologie, the Deutsche Gesellschaft für Neurologie and the Unione Italiana lotta alla Distrofia Muscolare, Foreign Associate Member of the Bekampfung der Muskelkrankheiten, and an Honorary Member of the Australian, Belgian, Brazilian, Indian, Polish, Spanish, Thai, Hong Kong and Venezuelan Neurological Associations. In 1978 he became the first British Honorary Member of the Japanese Neurological Association. He was elected as Honorary Member of the British Paediatric Association in 1984. In 1979 he became a Knight Bachelor and in 1989 received a life peerage as Lord Walton of Detchant.

$\mathrm{He}$ has visited and lectured in most countries throughout the world, and in 1966 he spent a month as Visiting Professor of Neurology at the Albert Einstein Medical College in New York.

He first began his research into various aspects of muscle disease when working with Professor F.J. Nattrass in 1951, and over the years built up an extensive research team at the Newcastle General Hospital in the Muscular Dystrophy Group Research Laboratories, where the clinical, genetic, pathological, histochemical, biochemical and electrophysiological aspects of musclar dystrophy and related diseases were being investigated.

He has published over 150 papers in the medical literature on neurological subjects, many of them concerned with diseases of muscle, and has also published monographs on 'Subarachnoid Haemorrhage' and 'Polymyositis' (the latter jointly with Professor Raymond Adams of Boston). In addition to his textbook, Essentials of Neurology (of which the sixth edition was published in 1989), he has also edited a multiple author work on Disorders of Voluntary Muscle (fifth edition published in 1985). In addition to editing a series of monographs on 'Major Problems in Neurology' for Saunders and Baillière Tindall, and coediting with Professor F.L. Mastaglia a book on Skeletal Muscle Pathology published in 1982 (second edition in preparation), he was also a contributor to the International Textbook of Medicine in three volumes, published by W.B. Saunders; his contribution to that work was later published separately as Introduction to Clinical Neuroscience (Baillière Tindall, 1983, second edition, 1987). He is also an advisory editor for the International Dictionary of Medicine and Biology (John Wiley Ltd) and senior editor of the Oxford Companion to Medicine, published by Oxford University Press, 1986. He was Editor-inChief of the Journal of the Neurological Sciences for 11 years from 1966 and is now Editor-in-Chief of Current Opinion in Neurology and Neurosurgery and of the Royal Society of Medicine International Congress and Symposium Series, as well as being a present or past member of the editorial boards of several other neurological journals.

In 1971 Lord Walton was elected Chairman of the Muscular Dystrophy Group of Great Britain \& Northern Ireland and also continues to act as Chairman of the World Federation of Neurology's Research Group on Neuromuscular Diseases. In 1989 he was elected President of the World Federation of Neurology, having been First Vice-President of the Federation from 1981 to 1989 and Chairman of its Research Committee from 1977 to 1989. From 1974 to 1978 he served on the Medical Research Council, having been previously a member of its Clinical Research Board and Systems Board and chairman of a grants committee.

He was President of the General Medical Council from 1982 to 1989 , having served from 1975 to 1982 as Chairman of the Council's Education Committee. From 1975 to 1982 he also served as one of the UK representatives on the EEC Advisory Committee on Medical Training. He was a member of Council of the Royal College of Physicians 1979-1989 and was President of the British Medical Association 1980-1982. In 1981 he was elected President of the Association for the Study of Medical Education. He was elected President of the Royal Society of Medicine 1984- 1986 and of the Association of British Neurologists 1987-1988.

His past appointments have included Staff Presi- 
dent of the Newcastle University Medical Student's Society, member of Council of the EEG Society of Great Britain, President and Honorary Secretary of the Newcastle-upon-Tyne and Northern Counties Medical Society, Honorary Secretary of the North of England Neurological Association, member of Council of the Neurological Section of the Royal Society of Medicine, of which section he has recently been made an Honorary member, a rare distinction, since the only other English neurologist so honoured is Macdonald Critchley.

There have been few who have had so distinguished a career, the only previous clinical neurologist to have achieved a peerage being Lord Brain and the only other British President of the World Federation of Neurology being Macdonald Critchley.

Perhaps the most surprising attribute is his lack of pretention. Despite all his honours, he is inordinately proud of his humble, County Durham origins and his accent in telling a Geordie joke is so genuine as to be incomprehensible. His capacity for work is limitless and his ability to simplify the most complex issues has meant that he continues to be in great demand to chair many committees.

To look at his diary of engagements would make many a younger man blanche, but his indefatigability continues unremittingly. With all this he has an eminently clubbable personality, is an excellent after-dinner speaker with a high reserve of anecdotes, quotations, wise saws and even poetry. One of his great claims to fame, in Detchant at least, was to have been made Captain of the local golf club, an honour in County Durham that took precedence in the local newspaper over his peerage.

Perhaps no account of Lord Walton's success would be complete without reference to two women in his life. His wife, Betty, has been the love of his life since he was first asked by her to carry her music at school. Her support has been paramount; their joint love of travel, music (she is a superb organist) and pride in their origins has helped to lighten his mighty load. A less recognized, but also indispensible help, has been his secretary of many decades, Rosemary Allen who, even in his so-called retirement, continues to serve him faithfully-more as a personal assistant than simply a secretary.

On a purely personal note, I first met John Walton about 35 years ago and, as with all of us, have watched his matchless progress with awe. As the years have passed, my admiration continues to grow and it is one of the greatest pleasures to work closely with him in the World Federation of Neurology, he as President and I as SecretaryTreasurer General.

It has been yet another great pleasure to edit this Festschrift issue of the Postgraduate Medical Jour$\mathrm{nal}$, in honour of his septuagenarian year. I look forward to being given the honour and privilege of doing something similar in his octogenarian year.

F. Clifford Rose, F.R.C.P. London Neurological Centre, 110 Harley Street, London WIN IAF, UK. 